\title{
VERSKI MOTIVI V PRAVLJICAH OSCARJA WILDA
}

\author{
Milena Mileva Blažıć \\ Pedagoška fakulteta univerze v Ljubljani, Ljubljana \\ milena.blazic@pef.uni-lj.si
}

Oscar Wilde, s polnim imenom Oscar Fingal O'Flahertie Wills Wilde, je bil rojen 16. oktobra $1854 \mathrm{v}$ Dublinu na Irskem, umrl pa je 20. novembra 1900 v Parizu v Franciji. V literarni zgodovini je splošno znan kot duhovit dramatik, esejist, pesnik in romanopisec. Njegova dela so bila sorazmerno zgodaj prevedena v slovenščino, npr. roman Slika Doriana Graya (1891, v sl. 1924), Lady Windermere: drama v štirih dejanjih (1892, v sl. 1921), Kako važno je biti resen (1895, v sl. 1967) itn. Wilde je bil rojen v aristokratski družini, oče Sir William Wilde je bil zdravnik in mati Jane Frances Elgee - umetniško ime Speranza - pesnica oziroma poetesa, ki je vodila literarni salon. Po Dublinu je Wilde študiral v Trinity Collegeu v Dublinu in v Magdalen Collegeu na Oxfordu klasično filologijo in je že kot študent izkazoval talent. Zato so v njegovih pravljicah pogoste omembe grških kipov, Adonisa, Narcisa ipd. Wilde je veliko potoval v Ameriko, London, Pariz, bil je vabljen predavatelj, duhovit govorec $\mathrm{z}$ aforističnim slogom. Nanj so vplivali dekadenca, esteticizem in simbolizem v viktorijanskem obdobju. Nedvomno je bil Wilde karizmatična oseba, saj je v kratkem življenju veliko potoval in predaval. Na osnovi članka Karizma teorije Marka Juvana (2014) je razvidno, da je imel Wilde vse značilnosti »kozmopolitskega zvezdniškega sistema« (str. 206).

Wilde se je leta 1855 v Dublinu poročil s Constance Lloyd (18581898). Pravljice je bral in/ali pripovedoval sinovoma Cyrylu (1885-1915) in Vyvyanu (1886-1967). Njegove pravljice so večnaslovniške (angl. 
crossover), kar pomeni, da jih lahko berejo mladi in odrasli. Zaradi Wildove zveze z lordom Douglasom sta se kasneje Oscar in Constanca ločila. Žena je odšla s sinovoma v Švico in jima spremenila priimek v Holland. Pisatelj je imel tri odmevne sodne procese zaradi javne istospolne zveze, zaradi katere je bil obsojen tudi na zapor (1895-1897). Stenogrami s sodišča so javno dostopni na medmrežju. V zaporu 1897 je napisal De Profundis, ki je posthumno objavljen 1905. V tem delu je znan Wildov esej Človeška duša v socializmu (1891, v sl. 1993), ki se navezuje tudi na kontekst pravljic. Leta 1891 se je Wilde zaljubil v lorda Alfreda Douglasa, s katerim sta bila par nekaj let, vendar je Douglasov oče, markiz Queensberryja, Wilda obtožil sodomije, kar je sprožilo sodne procese (»The Trial of Oscar Wilde, Printed in 1906 «s. d.) in zapor Pentonville ter zgodnjo smrt v Parizu, kamor se je po prestajanju zaporne kazni zatekel. $\mathrm{V}$ zaporu se je bolj približal veri. $\mathrm{V}$ študijskih letih se je nagibal k poganstvu, $v$ zaporniških letih $h$ krščanstvu (sprememba iz anglikanstva $v$ katolištvo na smrtni postelji), ker so ga zaradi kriminalizacije istospolnosti in sodnih procesov ter zapora domala vsi zapustili. Trije sodni procesi Oscarja Wilda leta 1895 so tudi študijski predmeti na nekaterih pravnih fakultetah (Linder, s. d.) in predmet številnih interdisciplinarnih znanstvenih člankov o literaturi in pravu (Wan 2011).

\section{Wilde in vera}

Wilde je bil veren na svoj način, kristjan anglikanske veroizpovedi; pravijo, da se je na smrtni postelji dal prekrstiti v katoliško veroizpoved (Holland in Hart-Davis 200o, 1224). Označevali so ga za ateističnega kristjana, vendar je v pravljicah uporabljal tudi motive iz svetovnih verstev, npr. antične motive (politeizem) in motive iz islama oziroma Orienta.

Wildov oče je bil protestant, sam pa se je v zaporu približal (katoliški) veri. V študijskih letih se je nagibal $k$ poganstvu, v zaporu Pentonville se je približal krščanstvu, obiskal je tudi papeža Pija IX. in mu celo na- 
pisal pesem, ki je bila objavljena v verski reviji The Month. V zaporu so ga domala vsi zapustili. O Wildovi veri obstajajo monografije, npr. The Faiths of Oscar Wilde: Catholicism, Folklore and Ireland (Killeen 2005).

\section{Wildove pravljice, 1888 in 1891}

Oscar Wilde je napisal dve zbirki, skupaj devet pravljic. Prva zbirka pravljic ima naslov Srečni kraljevič in druge pravljice (1888), v slovenščini je prvič objavljena kot Pravljice leta 1919 v prevodu Alojza Gradnika in z ilustracijami Avgusta Bucika. Vsebuje tudi štiri pravljice iz Wildove druge zbirke, Hiše granatnih jabolk (1891): Mladi kralj, Infantinjin rojstni dan, Ribič in njegova duša, Zvezdan. Naslednja slovenska zbirka, prav tako naslovljena Pravljice, je v prevodu Milana Jakliča izšla leta 1921. V knjigi so vključene pravljice iz prve zbirke: Srečni princ, Slavec in roža, Sebični ober (v prevodu Cirila Kosmača: Sebični velikan), Vdani prijatelj in Znamenita raketa ter druga besedila (pesmi v prozi).

Obe Wildovi zbirki pravljic Srečni kraljevič in druge pravljice (1888) in Hiša granatnih jabolk (1891) sta v integralni varianti vseh devetih pravljic in v prevodu Cirila Kosmača izšli leta 1959 v Knjižnici Kondor z ilustracijami Vladimirja Lakoviča in spremno besedo Josipa Vidmarja,. V Vidmarjevi spremni besedi otroci oziroma mladi naslovniki niso omenjeni, saj je zbirka, kljub temu da je tudi intencionalno namenjena otrokom, de facto namenjena odraslim oziroma je večnaslovniška (angl. crossover).

Wildove pravljice so izrazite avtorske pravljice, za razliko od modela ljudskih pravljic Jacoba in Wilhelma Grimma. Hans Christian Andersen je uveljavil model klasične pravljice, vendar je Wilde dodajal pravljicam izrazite literarne prvine. Intertekstualno se je navezoval na model ljudske pravljice, tudi na zbirko arabskih pravljic Tisoč in ena noč, npr. pravljico Ribič in duh, ki se pri bratih Grimm pojavlja kot Ribič in njegova žena (1812), pri Andersenu kot Mala morska deklica (1837), pri Wildu pa kot Ribič in njegova duša (1891). 


\section{Pravljice ali antipravljice}

Wildove pravljice so izrazito literarne, vendar če apliciramo teorijo Maxa Lüthija v knjigi Evropska pravljica: forma in narava (2011), se navezujejo na model ljudske (evropske) pravljice in imajo njene bistvene značilnosti, hkrati pa se kot izrazite avtorske oziroma literarne pravljice oddaljujejo od tega modela.

1. Enodimenzionalnost - Wildove pravljice so enodimenzionalne, dogajajo se na ravni čudeža, realni in pravljični svet nista ločena (Lüthi 2011, 1), literarni liki in pravljična bitja so človeku fizično blizu (str. 4). Tako, denimo, literarni liki, kot so kipi ali ptiči, govorijo, nastopajo pravljične osebe, npr. čarovnica, mala morska deklica, velikan ipd.

2. Ploskovitost - Wildove pravljice niso linearne, so kompleksne, čeprav so dogajajo na ravni nove enodimenzionalnosti, kjer je povsem samoumevno, da se ljudje in živali, npr. ptiči (Slavček in vrtnica), pogovarjajo, ali da se Ribič pogovarja s svojo dušo, da le-ta živi samostojno življenje v neki novi dimenziji.

3. Abstraktni slog - značilnost Wildovih pravljic nista abstraktni slog in uporaba nadpomenk (npr. gozd, grad; nekoč, nekje ...) kot v modelu ljudskih pravljic, ampak je izrazita uporaba podpomenk (glog ..., bog Adonis ..., Egipt, Indija ...). Kot literarni liki nastopajo berač, bog, duhovnik, duša, kralj, kraljevič, morska deklica, velikan, ptič (lastovček, slavček), pastir in zelo veliko obratov je, pri katerih so bogati ljudje sebični, revni nesebični (Zvezdan), s čemer izraža socialno temo, ki jo uteleša članek Duša človeka $v$ socializmu iz leta 1891. Tipični prislovni določili za čas (nekoč) in kraj (nekje), ki sta značilni za pravljice, vendar bolj za model ljudske pravljice (Grimmove pravljice) in manj za avtorske oziroma literarne pravljice, kot so npr. Wildove, se v besedilih sicer pojavljata, vendar sta čas in kraj določljiva, od konkretizacije (npr. Egipt) do posredne določljivosti (npr. ebenovec - indijsko drevo črne barve). Wildov prostor je lahko tudi sakralen (oltar, tempelj), vendar ima srce sakralnejši pomen kot cerkev (Srečni kraljevič), ljubezen pa je prostor večnosti in je dobesedno nad cerkvijo (Ribič in njegova duša). Wildove pravljice vsebujejo izjemno veliko elementov metalizacije (baker, srebro, svinec, 
zlato, železo), vendar so tudi elementi mineralizacije oziroma kamnov in dragih kamnov oziroma draguljev pogosti (beril, jantar, kristal, krizolit, nefrit, oniks, selenit, smaragd, turkiz idr., tudi slonova kost).

4. Izolacija in univerzalna povezanost - Wildovi pravljični liki so hkrati izolirani in univerzalno povezani $\mathrm{v}$ dogajanje. $\mathrm{V}$ njegovih pravljicah se pojavljajo tudi pravljični tipi ATU', npr. ATU 1620 - cesarjeva nova oblačila, ki so v pravljici Mladi kraljevič $\mathrm{z}$ drugačno poanto, $\mathrm{s}$ poudarjenim socialnim občutkom za bogate in revne. Za njegove pravljice lahko rečemo, da vsebujejo motive, motivne drobce in slepe motive (Adonis, ebenovina, Egipt, Endimionov kip, Indija, Memnon, Narcis idr.). Ker je živel ob koncu 19. stoletja, torej v času fin de siecla in dekadence, je ta značilnost njegovega sloga, ki jo je prenesel tudi v pravljice. Tu so vonji (cimet, glog, mira ...), vendar tudi cvetje/rastline/rože, ki jih izraža s podpomenkami in $\mathrm{z}$ vrstami, npr. georgine, krizanteme, lilije, lokvanj, mačehe, marjetice, nageljčki, narcise, orlice, potonike, sandalov cvet, spominčice, šmarnice, trobentice, trstika, vijolice, vrtnice (posebno mesto), zajčki, ptiči (lastovček, noj, pav, ščinkavec, slavček ipd.), sadje (češnje, slive idr.)

5. Sublimacija in vsevključenost -literarni motivi oziroma simboli, ki sestavljajo Wildove pravljice, ne izvirajo iz pravljic samih, ampak so skupni motivi (duša, senca; eros, tanatos) z dolgo literarnozgodovinsko tradicijo (antični miti, Biblija in drugi viri). Poleg vsakdanjih motivov v Wildovih pravljicah nastopajo pravljični motivi (pogovori z živalmi, npr. lastovčkom, s pravljičnimi bitji, npr. morsko deklico), ki so vsi vključeni $\mathrm{v}$ novo pravljično enoto ali antipravljico.

\section{Vergilijevo kolo}

V literarni vedi obstaja t. i. »Vergilijevo kolo« (lat. rota Virgilii) oziroma srednjeveška ponazoritev literarnih zvrsti, ki hierarhično $\mathrm{v}$ treh

1 ATU je mednarodna oznaka oziroma akronim na podlagi priimkov treh folkloristov (Antti Aarne, Stith Thompson, Hans-Jörg Uther), ki so objavili mednarodno klasificiran indeks pravljičnih tipov (Uther [2004] 2011). 
kategorijah navaja tri literarne sloge za tri stilne vrste (nizki, srednji in visoki stil), ki ustrezajo trem Vergilijevim delom, pastirko (Bukolika), didaktiko (Georgika) in epiko (Eneida), ki ponazarjajo tudi tri razvoje faze Vergilija. Na osnovi srednjeveške analize sloga, ki temelji na antični literaturi, se lahko slog Wildovih pravljic ponazori na osnovi literarnih motivov: drevesa, kraji, orodja, živali, imena (lastna) in družbeni stanovi (razredi/sloji).

\begin{tabular}{|c|c|c|c|}
\hline $\begin{array}{l}\text { Kategorije } \\
\text { analize }\end{array}$ & $\begin{array}{l}\text { Nizki slog (ruralna } \\
\text { poimenovanja) }\end{array}$ & $\begin{array}{l}\text { Srednji slog (mestna } \\
\text { poimenovanja) }\end{array}$ & $\begin{array}{c}\text { Visok slog (biblijska } \\
\text { poimenovanja) }\end{array}$ \\
\hline & J. in W. Grimm & H. C. Andersen & Oscar Wilde \\
\hline Drevesa & $\begin{array}{l}\text { drevo (bukev/čudovi- } \\
\text { to/dragoceno/grčasto/ } \\
\text { krasno/majhno/mla- } \\
\text { do/mogočno/največ- } \\
\text { je/prekrasno/rodovit- } \\
\text { no/srebrno/stoletno/ } \\
\text { suho/visoko/votlo/ } \\
\text { življenja) }\end{array}$ & $\begin{array}{l}\text { Prav z vašega vrta } \\
\text { so!« je rekel prodaja- } \\
\text { lec sadja ter mu poka- } \\
\text { zal jabolka in hruške. } \\
\text { (Andersen } 2005,41) \\
\text { Bezgova mamka } \\
\text { Poslednje sanje stare- } \\
\text { ga hrasta } \\
\text { Drevo (bezgovo/ } \\
\text { cvetoče/mogočno/ } \\
\text { pravo) } \\
\text { bezeg }(74)^{2} \\
\text { hrast }(44) \\
\text { hruške (17) } \\
\text { jabolka }(66)\end{array}$ & $\begin{array}{l}\text { Stebri, ki so bili iz } \\
\text { cedrovine, so bili ovi- } \\
\text { ti z ogricami rumenih } \\
\text { listkov. (Wilde } 2000 \text {, } \\
\text { 139) } \\
\text { Tam sem sedela z } \\
\text { mornarji, ki so pili } \\
\text { vino dveh barv in jed- } \\
\text { li ječmenov kruh in } \\
\text { drobne, okisane ribi- } \\
\text { ce na lovorjevih listih. } \\
\text { (str. 141) }\end{array}$ \\
\hline
\end{tabular}

2 Frekvenca pojavljanja motivov. 


\begin{tabular}{|c|c|c|c|}
\hline $\begin{array}{l}\text { Kategorije } \\
\text { analize }\end{array}$ & $\begin{array}{l}\text { Nizki slog (ruralna } \\
\text { poimenovanja) }\end{array}$ & $\begin{array}{l}\text { Srednji slog (mestna } \\
\text { poimenovanja) }\end{array}$ & $\begin{array}{c}\text { Visok slog (biblijska } \\
\text { poimenovanja) }\end{array}$ \\
\hline & J. in W. Grimm & H. C. Andersen & Oscar Wilde \\
\hline Imena & $\begin{array}{l}\text { Na robu velikega goz- } \\
\text { da sta živela ubog dr- } \\
\text { var in njegova žena } \\
\text { s svojima otrokoma, } \\
\text { fantičku je bilo ime } \\
\text { Janko in deklici Met- } \\
\text { ka. (Grimm 1993, 88) } \\
\text { Ljudska imena: Hans, } \\
\text { Janez, Janko, Lenčka, } \\
\text { Metka ... } \\
\text { Poklic: bremenski me- } \\
\text { stni godci, brezroka } \\
\text { deklica, hlapec, kme- } \\
\text { tič, krojač, pastir, pas- } \\
\text { tirica, popotnik ... } \\
\text { Funkcijska imena: } \\
\text { Drozgobrad, Jorin- } \\
\text { da in Jorindel, Pepel- } \\
\text { ka, Rdeča kapica, Sne- } \\
\text { guljčica, Špicparkeljc, } \\
\text { Trnuljčica, Vseved ... }\end{array}$ & $\begin{array}{l}\text { V neki vasi sta žive- } \\
\text { la dva moža in oba } \\
\text { sta imela enako ime. } \\
\text { Obema je bilo ime } \\
\text { Miklavž, toda eden je } \\
\text { imel štiri konje, dru- } \\
\text { gi pa enega samega; da } \\
\text { bi ju ločevali, so tiste- } \\
\text { ga, ki je imel štiri ko- } \\
\text { nje, klicali Miklavž, } \\
\text { tistega, ki je imel } \\
\text { samo enega konja, pa } \\
\text { Miklavžek. (str. 11) } \\
\text { Adolf, Gerda, Her- } \\
\text { man, Hlajmar, Jonas, } \\
\text { Kai, Maja, Ole Lahko- } \\
\text { noček idr. }\end{array}$ & $\begin{array}{l}\text { Adonis } \\
\text { bog, čigar Ime je } \\
\text { ljubezen } \\
\text { cesar in Nubijec } \\
\text { duša } \\
\text { ime krivega preroka } \\
\text { Ime, božje } \\
\text { Ime, ki ne sme biti } \\
\text { izgovorjeno } \\
\text { ime, morska deklica } \\
\text { Infantinja } \\
\text { Kajn } \\
\text { Narcis } \\
\text { Zvezdan }\end{array}$ \\
\hline Kraji & $\begin{array}{l}\text { cerkev (38) } \\
\text { gozd (446) } \\
\text { grad (327) } \\
\text { mesto (74) } \\
\text { pašnik (15) } \\
\text { vas (145) } \\
\text { vrt (38) }\end{array}$ & $\begin{array}{l}\text { cerkev (21) } \\
\text { dvorec (15) } \\
\text { gozd (261) } \\
\text { grad (238) } \\
\text { mesto (78) } \\
\text { vas (56) } \\
\text { vrt (90) }\end{array}$ & $\begin{array}{l}\text { cerkev (15) } \\
\text { dvorec (65) } \\
\text { gozd (52) } \\
\text { grad (9) } \\
\text { jug (2) } \\
\text { mesto (25) } \\
\text { vrt (117) } \\
\text { vzhod (5) } \\
\text { zahod (9) } \\
\text { slast (2) }\end{array}$ \\
\hline
\end{tabular}




\begin{tabular}{|c|c|c|c|}
\hline $\begin{array}{l}\text { Kategorije } \\
\text { analize }\end{array}$ & $\begin{array}{l}\text { Nizki slog (ruralna } \\
\text { poimenovanja) }\end{array}$ & $\begin{array}{l}\text { Srednji slog (mestna } \\
\text { poimenovanja) }\end{array}$ & $\begin{array}{c}\text { Visok slog (biblijska } \\
\text { poimenovanja) }\end{array}$ \\
\hline & J. in W. Grimm & H. C. Andersen & Oscar Wilde \\
\hline Orodja & $\begin{array}{l}\text { njiva (22) } \\
\text { orati (2) } \\
\text { plug (8) } \\
\text { palica (22) } \\
\text { nož (39) }\end{array}$ & $\begin{array}{l}\text { meč }(6) \\
\text { palica }(6) \\
\text { plug }(2) \\
\text { vžigalnik (28) } \\
\text { nož (17) }\end{array}$ & $\begin{array}{l}\text { meč }(8) \\
\text { kelih }(3) \\
\text { misel }(7)\end{array}$ \\
\hline $\begin{array}{l}\text { Razred } \\
\text { (socialni) }\end{array}$ & 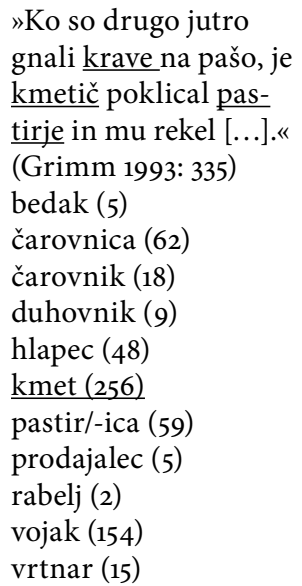 & $\begin{array}{l}\text { „'Vaše ime? Vaš polo- } \\
\text { žaj?'« je vprašal stra- } \\
\text { žar tistega, ki je prvi } \\
\text { stopil iz kočije.» } \\
\text { čarovnica (6o) } \\
\text { čarovnik (15) } \\
\text { duhovnik (15) } \\
\text { kmet (8o) } \\
\text { mojster (35) } \\
\text { pastir (6o) } \\
\text { prodajalec (26) } \\
\text { rabelj (6) } \\
\text { soldat (78) } \\
\text { vojak (137) } \\
\text { vrtnar (49) }\end{array}$ & $\begin{array}{l}\text { čarovnica (9) } \\
\text { čarovnik (2) } \\
\text { gobavec (8) } \\
\text { kralj }(228) \\
\text { kraljevič (32) } \\
\text { vojak (10) }\end{array}$ \\
\hline
\end{tabular}




\begin{tabular}{|c|c|c|c|}
\hline \multirow[t]{2}{*}{$\begin{array}{c}\text { Kategorije } \\
\text { analize }\end{array}$} & $\begin{array}{l}\text { Nizki slog (ruralna } \\
\text { poimenovanja) }\end{array}$ & $\begin{array}{l}\text { Srednji slog (mestna } \\
\text { poimenovanja) }\end{array}$ & $\begin{array}{l}\text { Visok slog (biblijska } \\
\text { poimenovanja) }\end{array}$ \\
\hline & J. in W. Grimm & H. C. Andersen & Oscar Wilde \\
\hline Živali & $\begin{array}{l}\text { Bobnarica in } \\
\text { smrdokavra } \\
\text { Gosja pastirica } \\
\text { Lisica in mačka } \\
\text { Mačka in miš } \\
\text { Morski prašiček } \\
\text { Osliček } \\
\text { Pes in vrabec } \\
\text { Pojoči škrjanček } \\
\text { Sova } \\
\text { Vrabec in njegovi štir- } \\
\text { je otroci } \\
\text { Žabji kralj } \\
\text { Zajec in jež }\end{array}$ & $\begin{array}{l}\text { Grdi raček } \text { »K njim } \\
\text { poletim, h kraljevskim } \\
\text { pticam }{ }^{3} ![\ldots] \text { Bolje, da } \\
\text { me ubijejo one, kot da } \\
\text { me ščipajo race, klju- } \\
\text { jejo kokoši, kot da me } \\
\text { brca dekla, ki skrbi za } \\
\text { kokošnjak, in da pozi- } \\
\text { mi trpim silne muke!« } \\
\text { (Andersen } 1998,161 \text { ) }\end{array}$ & $\begin{array}{l}\text { Ribič in njegova duša } \\
\text { »In v tistem vrtu se } \\
\text { sprehajajo beli pavi } \\
\text { in pavi z modrimi } \\
\text { prsmi.." (str. 146) } \\
\text { Slavček in vrtnica } \\
\text { (slavček) } \\
\text { Srečni kraljevič } \\
\text { (lastovček) }\end{array}$ \\
\hline
\end{tabular}

Ravno z visokim slogom da Wilde svojim pravljicam biblijski, privzdignjen in slovesen slog. $S$ tem presega kristjanizirano pojmovanje boga, saj velikokrat pravi »bog, čigar Ime je ljubezen«.

\section{Videc/prerok}

Za Wildove pravljice je značilna tudi estetika nasprotnosti, za razliko od modela ljudske pravljice, npr. J. in W. Grimma, za katerega je značilna estetika istovetnosti, ko pravljice izpolnjujejo tradicionalna pričakovanja bralcev. Wildove pravljice, četudi temeljijo na modelu ljudske pravljice in estetike istovetnosti (npr. J. in W. Grimm: Ribič in njegova žena - O. Wilde: Ribič in njegova duša), se od nje tudi odmikajo (npr. H. C. Andersen: Mali Miklavž in veliki Miklavž - O. Wilde: Vdani prijatelj (Mali Hans in mlinar Hugo)).

3 Tj. labodom. 
Literarna veda Wilda definira tudi kot dandyja, tj. pripadnika tistega družbenega tipa v drugi polovici 19. st. v Angliji, za katerega so značilni ekstravaganca, konverzacija, oblačenje in status zvezdnika (Juvan 2014).

V članku Model kanonizacije evropskih kulturnih svetnikov Marijan Dović (2012) razmišlja o statusu »izbranca« v literaturi, kar O. Wilde zagotovo je. O njegovem življenju je napisano skoraj več literature kot o njegovem delu. Dovič postavlja naslednje kriterije: vitae (posameznikovi potenciali), inventio (utemeljitev statusa), cultus (reprodukcija) in virtutes (družbene implikacije). Ker bi aplikacije Dovićeve teorije presegla namen pričujočega članka in bo teorija aplicirana $v$ enem izmed naslednjih člankov, bi bilo pri Wildu smiselno omeniti podkategorije vitae (potenciali posameznika). To so opera (dela), persona (osebnost in pojava), aenigma (»transgresije«) in acta (kulturni »dosežki«). Vse te značilnosti so bile tipične za Wilda in se zrcalijo v vseh devetih pravljicah. Dović omenja tudi položaj vidca/preroka (Dović 2012, 74). Pri Wildu so v vseh pravljicah anticipirani motivi umetnika vidca/preroka, še posebej v Srečnem kraljeviču (1888), v katerem je predvidel svoje življenje. Dokler je užival status zvezdnika (dela, osebnost, transgresija (istospolnost) in kulturni dosežki), je bil podoben kipu srečnega kraljeviča (bogat, lep, mlad, visok (družbeni status)), ko pa je bil obsojen in v zaporu, ga je večina pozabila, mu odrekla podporo in - kar ga je najbolj prizadelo - pustil ga je tudi partner, Lord Douglas imenovan Bossie, ki je bil z Wildom, dokler je bil ta bogat in slaven.

Za pravljico Sebični velikan, v kateri Wilde tematizira sebičnost/nesebičnost, bi lahko rekli, da je neke vrste Wildova samoprerokba - tudi sam je potoval od egocentrizma do sociocentrizma.

$\mathrm{V}$ pravljici Infantinjin rojstni dan, ki je nastala ob Velazquezovi mojstrovini Las Menina (1656), je ob implicitnem slavljenju velikih umetniških predhodnikov hkrati obujal in izumljal novo tradicijo (estetika inovacije) in tematiziral status izbranca, umetnika, zaljubljenca prek manjšega pritlikavca izmed dveh (na Velazquezovi sliki). 
V obsežni pravljici Ribič in njegova duša tematizira ljubezen med dvema bitjema različne strukture (morske - zemeljske), različnih spolov (moškega - ženskega), vendar ima podoba morske deklice zgornji del telesa ženski, spodnji del pa »ribji« oziroma ga nima. Zaradi zaljubljenosti v morsko deklico, ki je alter ego Lorda Alfreda Douglasa (Bossie), se pravljični lik spremeni iz dobrega v slabega, zato si odreže senco oziroma se odpove duši, kar je Mefistov motiv, in sicer ko reče: "Senca je telo duše.« Na koncu pravljice oziroma antipravljice, ko Ribič brez duše hodi po svetu in počne hudodelstva (tako kot tudi Wilde, kar je zapisano v stenogramih sodnih procesov), oba literarna lika umreta oziroma naredita samomor, kar je tudi tabu. Zato ju duhovnik pokoplje zunaj cerkvenega obzidja, ko pa duhovnika naslednji dan presenetita dve roži, ki sta opojnega vonja in sta prerastli oziroma se spletli čez cerkveni obok, predlaga, da oba nesrečna zaljubljenca (samomorilca) pokopljejo znotraj cerkvenega pokopališča. $V$ tej pravljici, ki je leta 1891 preroško anticipirala Wildovo usodno zaljubljenost $v$ bitja drugega konteksta/spola, njegovo samoreferenčno ukvarjanje z dobrim in zlim, znotraj samega sebe in družbe, s poudarjanjem lastne pozicije, sublimirane v pravljico, domnevno za otroke, je napisal prerokbo in vizijo svoje prihodnosti ali kategorije genialnosti "grešnika" (boemskost, erotika, opojne substance).

\section{Večnaslovniškost Wildovih pravljic}

Vseh devet Wildovih pravljic, navkljub dejstvu, da jih je avtor domnevno namenil otrokom in da jih je pripovedoval svojima sinovoma, so večnaslovniške (angl. crossover) in ustrezajo kriterijem klasične oziroma večnaslovniške literature na osnovi teorije Bettine KümmerlingMeibauer ([1999] 2004, IX-XIV). Wildove pravljice so inovativne, reprezentativne, estetske, hkrati enostavne in kompleksne, predstavljajo otrokov svet (v manjši meri), so domišljijske, večpomenske in večnaslovniške. 


\title{
Primerjalna analiza najpogostejših verskih motivov ${ }^{4}$
}

\author{
Srečni kraljevič in druge pravljice, 1959 - The Happy Prince and Other \\ Tales, 1888
}

\section{Srečni kraljevič in druge pravljice (The Happy Prince and Other Tales)}

Splošno znano je, da je pravljica Srečni kraljevič neke vrste Wildova avtobiografija, tako kot je avtobiografska Andersenova pravljica Grdi raček.

1. David je pregledal ljudstvo, ki je bilo pri njem, in mu je postavil poveljnike čez tisoč in poveljnike čez sto. (2 Sam 18,1)

2. Deček ni nič vedel, Jonatan in David pa sta vedela za stvar. Jonatan je dal svoje orožje dečku, ki je bil z njim, in mu rekel: "Pojdi, nesi ga v mesto! «Ko je deček odšel, se je David vzdignil izza kamna Ezela, padel z obrazom na zemljo in se trikrat priklonil. Potem sta drug drugega poljubila in drug nad drugim jokala, David posebno močno. (1 Sam 20,39-41)

3. Kako sta padla junaka sredi boja! Jonatan je preboden na tvojih višavah! (2 Sam 1,25)

4. Hudo mi je za teboj, moj brat, Jonatan! Zelo si mi bil prijeten. Tvoja ljubezen mi je bila čudovita, bolj kot ženska ljubezen. ${ }^{5}$ (2 Sam 1,26)
1. Visoko nad mestnim središčem je na visokem stebru stal kip srečnega kraljeviča. (Wilde 200o, 7)

2. »Toplo ti je zato, ker si storil dobro dejanje, « je rekel kraljevič. (str. 15)

3. In tako je lastovček izbral veliki rubin iz kraljevičevega meča in z njim v kljunu zletel nad mestnimi strehami. (str. 12)

4. „Prinesi mi dve najdragocenejši stvari iz mesta, " je rekel bog enemu od svojih angelov. In angel mu je prinesel svinčeno srce in mrtvo ptico. »Prav si izbral, « je rekel bog, "zakaj v mojem nebeškem vrtu bo ta drobna ptička večno prepevala in v mojem zlatem mestu me bo srečni kraljevič slavil!« (str. 21)

4 Vsi biblični citati so iz spletne verzije Svetega pisma: Slovenski standardni prevod 3 (Društvo Svetopisemska družba Slovenije, [1996] 2021).

5 Podčrtala M. M. Blažić. Eksplicitna biblijska aluzija na istospolnost in implicitno priznavanje enakovrednosti istospolne ljubezni s sklicevanjem na Biblijo. 


\section{Slavček in vrtnica (The Nightingale and the Rose)}

Wildova antipravljica oziroma pravljica s tragičnim koncem se sicer navezuje na ironični Andersenovi pravljici Kraljična na zrnu graha in Svinjski pastir. V pravljici Slavček in vrtnica se Wilde intertekstualno navezuje na antični motiv Filomene - lastovice ali slavca. Simbol slavca je značilen za pesnike in je t. i. »literarna ptica« (Ferber 2012, 138) od Aristofanovih Ptičev dalje. Srednjeveški minnesingerji in trubadurji so pisali o pesniku slavcu, Keats je napisal tudi Odo slavčku, Andersen pravljico Slavec, C. Baudelaire Albatrosa ... in slavci oziroma ptiči so ponavadi samostalniki moškega spola.

Wildova pravljica Slavček in vrtnica z motivom trna je srednjeveški motiv. Ko slavček poje vrtnici do spomladi, včasih pritisne prsa na rožni trn, da poveča bolečino (v pesmi). Ferber v slovarju literarnih motivov ta motiv povezuje $\mathrm{z}$ Omarjem Hajamom in s perzijskim ptičem »bulbulom«, ko ptič bulbul/slavček poje žalostinko vrtnici.

1. In zgrabil je mestne starešine, vzel puščavsko trnje in osat ter $\mathrm{z}$ njimi dal vedeti možem v Sukótu. (Sod 8,16)

2. In vsa drevesa so rekla trnovemu grmu: "Pridi ti, kraljuj nad nami!« (Sod 9,14)

3. Da pa se zaradi vzvišenosti razodetij ne bi prevzel, mi je bil dan $\mathrm{v}$ meso trn, satanov sel, ki naj bi me tepel, da se ne bi prevzel. (2 Kor 12,z)

4. Kot škrlaten trak sta tvoji ustni, / tvoja usta so ljubka. / Njegova usta so sama sladkost, / ves očarljiv je. / Tvoje prsi naj bodo kot grozdi vinske trte / in vonj tvojega diha kakor jabolka, / tvoja usta kot najboljše vino, / ki teče mojemu ljubemu v slast, / drsi po ustnicah spečih. (Vp $4,3,5,16,9 b-10$ )
1. Ko je mesec zasijal na nebu, je slavček odletel k rožnemu grmu in pritisnil svoje prsi k trnu. Vso noč je pel s svojimi prsmi, nabodenimi na trn, in mrzli kristalni mesec se je sklanjal z neba in poslušal. (Wilde 200o, 26)

2. Vso noč je pel in trn je prodiral globlje in globlje v njegove prsi in kri njegovega življenja je odtekala iz njega. (str. 26)

3. Za plačilo pa zahtevam samo to, da boš zvesto ljubil, zakaj ljubezen je modrejša od modrosti, čeprav je modrost modra, in mogočnejša od oblasti, čeprav je oblast mogočna. Njena krila so ognjene barve in ognjene barve je njeno telo. Njene ustnice so sladke kakor med in njen dih je kakor kadilo. (Str. 25) 


\section{Sebični velikan (The Selfish Giant)}

Pravljica Sebični velikan je najkrajša Wildova pravljica; tematizira literarni lik sebičnega velikana, ki na začetku vidi, da se otroci igrajo na njegovem vrtu, potem jim to prepove, zato v njegovem vrtu nastopi zima, in na koncu dovoli otrokom, posebno enemu dečku, ki je kristjanizirani lik izbranca, da se igra in ga celo poljubi (na usta). V tej pravljici so eksplicitni verski motivi, posebej motiv Kristusa.

1. Gospod Bog je zasadil vrt proti vzhodu v Edenu in je tja postavil človeka, katerega je bil izoblikoval. (1 Mz 2,8)

2. Gospod Bog je dal, da je iz zemlje pognalo vsakovrstno drevje, prijetno za pogled in dobro za jed, tudi drevo življenja v sredi vrta in drevo spoznanja dobrega in hudega. (1 Mz 2,9)

3. „Če ne vidim na njegovih rokah rane od žebljev in ne vtaknem prsta v rane od žebljev in ne položim roke v njegovo stran, nikakor ne bom veroval.« (Jn 20,25)
1. Leta so tekla in velikan se je zelo postaral in zelo oslabel. Ni se mogel več igrati, zato je sedel v velikanskem naslanjaču, gledal, kako so se otroci igrali, in občudoval svoj vrt. (Wilde 2000, 34)

2. V najbolj oddaljenem kotu vrta je stalo drevo, ki je bilo pregrnjeno s čudovitim belim cvetjem. (str. 37)

3. «Kdo je bil tako predrzen, da te je

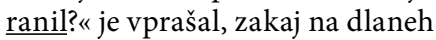
malega fantka sta bili rani od dveh žebljev in rani od dveh žebljev sta bili na njegovih drobnih nogah. (str. 37)

\section{Vdani prijatelj (The Devoted Friend)}

Vdani prijatelj je pravljica $\mathrm{z}$ okvirno zgodbo in osrednjo pripovedjo o nesebičnem revnem Hansu in sebičnem bogatem mlinarju. Prvi, ki je prispodoba za nesebičen nižji socialni razred, utone, drugi, ki je prispodoba za sebični višji razred, pa cinično ugotovi, da ne bo več »radodaren«, ker je revni Hans, ki bi mu »skoraj bil dal svojo samokolnico«, utonil, samokolnica pa je že polomljena in mu je »res v napoto«; Wilde torej tematizira dihotomije (bogat - reven, pristen prijatelj - nepristen prijatelj, sebičnost - nesebičnost ipd.), zato je tudi ta pravljica - antipravljica. 
1. Tedaj se jim je pridružila skupina hasidejcev, vrlih mož v Izraelu, ki so bili vsi vdani postavi. (1 Mkb 2,42)

2. Obrazu daje podobo človeško $\underline{\text { srce, }}$ bodisi v dobro bodisi v hudo.

(Sir 13,25)

3. Bodi velikodušen do reveža, ne puščaj ga, da bi na vbogajme čakal. (Sir 29,8)

4. Sebično oko se ne zadovolji s svojim 3 . deležem, hudobna krivičnost mu suši dušo. (Sir 14,9)

5. Značaj lažnivega človeka vodi v nečast in njegova sramota je stalno z njim. (Sir 20,26)
1. Obrazu daje podobo človeško srce, bodisi v dobro bodisi v hudo. Lenoba je velik greh in meni ni prav nič všeč, da bi bil kdorkoli od mojih prijateljev len in malomaren. (Wilde 2000, 47)

2. "Potemtakem je popolnoma jasno, da $v$ tvojem značaju ni prave nobenega sočutja, « je rekel pižmovec. (str. 51)

»Kakšne pa so, prosim, po vašem mnenju dolžnosti vdanega prijatelja? « (str. 38)

\section{Imenitna raketa (The Remarkable Rocket)}

$\mathrm{V}$ celotni pravljici oziroma antipravljici - saj glavni literarni lik, Imenitna raketa, na koncu tragično konča - Wilde tematizira »sedem grehov«, predvsem napuh. Implicitno tematizira tudi zvezdniški status, ne le svojega, ampak tudi drugih. Osnovni zaplet, poleg okvirne zgodbe (poroka kraljevega sina), je pogovor med pirotehničnimi literarnimi liki, osrednjim - Imenitno raketo, Bengalskim ognjem in Rimsko svečo.

1. Napuh vodi v pogubo in razkroj, lahkomiselnost te pa pripelje $\mathrm{v}$ ponižanje in veliko pomanjkanje, zakaj lahkomiselnost je mati lakote.

(Tob 4,13b)

2. Pred razsulom hodi napuh, pred padcem ošabnost duha. $(\underline{\operatorname{Prg} 16,18)}$

3. Okrási se z vzvišenostjo in veličastvom, obleci se dostojanstvo in sijaj! ( (Job 40,10)
1. Edino, kar obdrži človeka vse življenje na površju, je zavest, da so vsi drugi neskončno manjvredni, in to je občutek, ki sem ga zmeraj gojila. (Wilde 2000, 57)

2. „Slaba raketa? Slaba raketa?« je rekla, ko se je vrtela v zraku. »Nemogoče! Slavna raketa, tako je rekel možakar. Slabo in slavno se sliši skoraj enako in pravzaprav večkrat tudi je enako.«In je padla v blato. (str. 61)

3. "To bo odposlanstvo, « je rekla raketa in se potrudila, da bi bila videti kar se da dostojanstvena. (str. 65) 
Wilde uvaja tudi prvine sodobne pravljice, npr. narcizem, kar pa presega namen obravnave pričujočega članka.

Hiša granatnih jabolk, 1959 - The House of Pomegranates, 1891

Pravljice v zbirki Hiša granatnih jabolk tematizirajo umetnika, ki verjame v svoje talente in pomen umetnosti ter izjemnih oseb. Že v naslovu se pojavlja verski motiv - granatno jabolko. Kot klasični filolog je Wilde dodal še intertekstualnost s Persenofo (Isis), ki jo simbolizira granatno jabolko.

1. Na robu oblačila pa narêdi granatna jabolka iz višnjevega in rdečega škrlata in karmezina, okrog in okrog po njegovem robu, in med njimi okrog in okrog zlate zvončke: zlat zvonček in granatno jabolko, zlat zvonček in granatno jabolko okrog in okrog po robu vrhnjega oblačila! (2 Mz 28,33-34)
1. Njegovi lasje so temni in kodrasti, njegove ustnice so rdeče kakor granatno jabolko in njegove velike oči so sanjave. (Wilde 2000,16 )

2. Ne biseri ne granati je ne morejo preplačati in niti ni na prodaj na trgu. (Str. 23)

3. Temnordeči metulji z zlatim prahom na krilih so se spreletavali sem in tja ter po vrsti obiskovali cvet za cvetom, drobni martinčki so se priplazili iz razpok v zidu in se zleknjeni sončili v beli pripeki, granatna jabolka so se od vročine razklala in razpokala ter pokazala svoja krvaveča rdeča srca. (str. 88)

4. Trgali smo $\mathrm{z}$ dreves granatna jabol$\underline{\mathrm{ka}}$, jih lomili in srkali sladki sok. (str. 128)

5. Ko sem tisto noč ležala v čajnici, ki je v Ulici granatne jablane, je vstopila cesarjeva straža in me dopeljala na dvor. (str. 135)

\section{Mladi kralj (The Young King)}

Wildova pravljica o Mladem kralju, ki noče biti kronan na osnovi zunanjih atributov (obleka, krona ...), je antipod Andersenovi ironični pravljici Cesarjeva nova oblačila. 
1. Stopil je k njemu in ga poljubil. (1 Mz 27,27)
1. Videli so ga tudi, tako so namreč pripovedovali, kako je pritiskal svoje vroče ustnice na marmornato čelo starinskega kipa, ki so ga odkrili v strugi, ko so kopali temelje za nov kamniti most; na kipu je bilo vklesano ime Hadrijanovega bitinskega sužnja. In nekoč je prebedel vso noč in opazoval, kako mesečina obliva srebrni Endimionov kip. (str. 71)

2. Stal je pred Kristusovo podobo in na njegovi desnici in na njegovi levici sta bili čudoviti zlati posodi, kelih z rumenim vinom in stekleničica s posvečenim oljem. Pokleknil je pred Kristusovo podobo in velike sveče so svetlo zagorele pri tabernaklju, posutem $\mathrm{z}$ dragulji, in dim kadila se je v tenkih modrih kolobarčkih vijugal po cerkvi. Sklonil je glavo v molitev in duhovniki v svojih svečanih oblačilih so se splazili od oltarja. (str. 84)

\section{Infantinjin rojstni dan (The Birthday of the Infanta)}

Wildova pravljica s tragičnim koncem se navezuje na sliko Las Meninas Diega Velázqueza ([1656] s. d.), na kateri je devet bitij, osem oseb in pes. Dve izmed oseb sta pritlikavca na desni strani in Wilde je napisal dvodelno pravljico, v kateri je prvi del posvetil žalovanju Infantinjinega očeta, španskega kralja, za svojo zastrupljeno ženo, ki jo je balzamiral. V drugem delu, ko se pritlikavec sprehaja po sobanah $\mathrm{z}$ ogledali in ko se sooči z lastno identiteto oziroma videzom, ob tem tragičnem spoznanju in samouvidu pritlikavec umre oziroma mu »poči srce«. Infantinja na koncu cinično reče, da naj odslej k njej prihajajo le tisti, ki »nimajo srca 
1. Potem je zapovedal svojim služabnikom zdravnikom, naj njegovega očeta balzamirajo. In zdravniki so balzamirali Izraela. $\left(1 \mathrm{Mz}_{50,2}\right)$

2. Ta je stopil $\mathrm{k}$ Pilatu in prosil za Jezusovo telo. In snel ga je s križa, ga zavil $\mathrm{v}$ kos platna in položil $\mathrm{v}$ grob, izdolben v skalo, kamor ni bil še nihče položen. Bil je dan pripravljanja in bližala se je sobota. (Lk 23,52-54)
1. Tako neizmerno jo je imel rad, da mu je še grob ni smel zakrivati. Balzamiral jo je bil neki arabski zdravnik [...]. (Wilde 2000, 91)

2. Kraljičino truplo je še zmeraj ležalo na mrtvaškem odru, pregrnjenem s preprogami, $v$ dvorni kapeli iz črnega marmorja, kakor so ga tja prinesli menihi tistega vetrovnega marčnega dne pred skoraj dvanajstimi leti. (str. 91)

\section{Ribič in njegova duša (The Fisherman and His Soul)}

Pravljica oziroma antipravljica Ribič in njegova duša velja za najkompleksnejšo Wildovo pravljico. Posvetil jo je Alici, monaški princesi. Pravljica tematizira ljubezen ribiča do drugačnega bitja - morske deklice. Če želi biti z njo, se mora znebiti duše. V nadaljevanju oziroma v tretjem poskusu odreže »senco, ki je telo duše«, zato v obsežni pravljici literarni lik ribiča počne grozodejstva, ker nima »duše«. Konec je tragičen, saj obe bitji iz tostranstva (ribič) in onostranstva (morska deklica) kot tudi mitična duša na koncu umrejo. To je torej antipravljica, vendar iz njunih teles, sprva pokopanih zunaj »svete cerkvene zemlje«, zraseta cvetova »omamnega vonja«, ki duhovnika prepričata, da »posveti« njuno ljubezen in ju pokoplje znotraj »svete zemlje«. Besedilo je izjemno kompleksno, tematizira motiv gospodarja in hlapca oziroma ribiča in sence, $s$ številnimi simboli in $\mathrm{z}$ večpomenskostjo. 
1. Njegova duša se je navezala na Dino, Jakobovo hčer; vzljubil je dekle in ljubeznivo $\mathrm{z}$ njo govoril. (1 $\mathrm{Mz}$ 34,3)

2. Potem je Heberjeva žena Jaéla pograbila šotorski klin, vzela kladivo $\mathrm{v}$ svojo roko, se mu tiho približala in zabila klin v njegova senca tako, da se je zarinil v zemljo. $\mathrm{V}$ trdnem spanju se je stresel in umrl. (Sod 4,21)

3. In Bog jih je blagoslovil in rekel: »Plodite se in množite, napolnite vse morsko vodovje! In ptice naj se množijo na zemlji!« (1 Mz 1,22)
1. «Mala morska deklica, mala morska deklica, rad te imam! Vzemi me za ženina, rad te imam!« (Wilde 200o, 114)

2. "Tisto, čemur ljudje pravijo senca telesa, ni senca telesa, temveč je telo duše. Pojdi na obalo, obrni hrbet proti mesecu in odreži od nog svojo senco, ki je telo tvoje duše, in ukaži svoji duši, naj te zapusti, in ona te bo zapustila.« (Str. 124)

3. In ko je [duhovnik] prišel na obalo, je blagoslovil morje in vsa divja bitja, ki živijo v njem. Blagoslovil je tudi favne in drobna bitja, ki plešejo v gozdu, in svetlooka bitja, ki kukajo izza listja. Blagoslovil je vsa bitja tega božjega sveta, in ljudje so bili polni veselja in začudenja. (str. 154)

\section{Zvezdan (The Star-Child)}

1. „Kje je ta, ki se je rodil kot judovski 1. kralj? Videli smo namreč, da je vzšla njegova zvezda, in smo se mu prišli poklonit.« (Mt 2,2)

2. Ne maščuj se in ne bodi zamerljiv do sinov svojega ljudstva, temveč ljubi svojega bližnjega kakor samega sebe; jaz sem Gospod. (3 Mz 19,15)

2. In glej, pristopil je gobavec, se poklonil pred njim do tal in rekel: »Gospod, če hočeš, me moreš očistiti.« (Mt 8,2)
1. Z neba je padla zelo svetla in prekrasna zvezda. (Wilde 200o, 114)

2. In stari duhovnik ga je večkrat poklical k sebi in ga skušal učiti ljubezni do bližnjega [...]. Kdo pa si, da prinašaš bolečino v stvarnikov svet? (str. 159, 160)

3. Pred mestnimi vrati je bil gobavec. (str. 171)

Iz preglednice je razvidno, da je Wilde poznal antično literaturo, Biblijo in druga verstva, da je bil izjemno izobražen in tudi izjemno nadarjen. Za njegove pravljice bi lahko rekli, da so homo narrans (Uther 
[2004] 2011) in homo ludens (Huizinga [1938] 2003) ter dokaz Paula Armstronga ([2013] 2015): Kako se literatura igra $z$ možgani.

Wildove pravljice so sinteza literature in pravljice, vsebine in forme ter literature in filozofije. Pisatelj je bil izobražen v Oxfordu, v pravljicah je inovativno združil tezo (pravljice) in antitezo (antipravljice) v novo sintezo (literarne pravljice). Kot pravljičar je hkrati kritik in umetnik - umetnik kot družbeni kritik, posebej v pravljicah, ki so za Wildov krog veljale za paraliterarno vrsto. Avtor v vseh pravljicah združuje binarnosti, ki temeljijo na modelu ljudske pravljice (Propp. [1928] 2005), vendar jih inovativno združi v novo sintezo. Njegove pravljice so par excellence inovativen most med modelom ljudske in sodobne pravljice; literarna pravljica je sinteza protislovij ustne in pisne tradicije, besedil za otroke in za odrasle, ljudskega in avtorskega.

\section{Metoda}

Za pričujoči članek sta bili uporabljeni deskriptivna metoda in metoda literarne analize devetih Wildovih pravljic v slovenščini, ki jih je iz angleščine leta 1959 prevedel Ciril Kosmač. Na koncu članka je potrebno omeniti dve izjemni ilustratorki Wildovih pravljic.

Leta 1993 je izšla v zbirki Velike slikanice Wildova pravljica Srečni kraljevič z ilustracijami Marije Lucije Stupica (1950-2002), ki je leta 1976 diplomirala na ALU. Leta 2000 sta izšli obe zbirki oziroma integralna verzija devetih Wildovih pravljic z ilustracijami Alenke Sottler.

\section{Zaključek}

Wildove pravljice so predmet številnih raziskovanj, ne le s stališča verskih in drugih motivov, vendar se je bilo v pričujočem članku potrebno osredotočiti na verske prvine $\mathrm{v}$ pravljicah. V avtorjevih pravljicah se pojavljajo tudi motivi, motivni drobci in slepi motivi iz svetovnih verstev, npr. Apolon, Armenec, bakreni prstan (Gigesov), bazar, bengal- 
ski ogenj, bičanje s trnjem, derviš, divan, duhovnik s poševnimi očmi, Egipt, evnuhi, gong, Indija, Izida in Oziris, Jutrovo, kaftan, Koran, leopard (leopardove šape), levje kože, malik, Meka, Nil, Nubijci, opij, paviljon, piramide, poganska bitja, rimska sveča, Samarkand, Sirijci, slon, srebrni polmesec, suženj, tempelj, tiger (tigrove šape), turban, votlina, Židje idr.

Wilde v vseh devetih pravljicah opisuje verski motiv mučeništva, preko biblijske prispodobe mučeništva (trpljenje in žrtev), zato so njegove pravljice antipravljice, saj imajo nesrečen konec - pravljični lik umre, njegova ideja pa preživi. Ker so antipravljice, bi se lahko iz Wildovega naslova preimenovale v implicitni naslov, npr.: Srečni kraljevič v Nesrečni kraljevič, Slavček in vrtnica v Mučenik in prevzetnica, Sebični velikan $\mathrm{v}$ Nesebični velikan, Vdani prijatelj v Nezvesti prijatelj, Imenitna raketa $\mathrm{v}$ Neimenitna/Prevzetna raketa, Infantinjin rojstni dan $\mathrm{v}$ Smrt pritlikavca, Ribič in njegova duša v Ribič brez duše, Zvezdan v Brezdušnost - duša. Mladi kralj ali Pristni kralj zavrne kronanje in želi biti kronan s trnovo krono, imeti lilije in skromno platno okoli pasu. Wilde opiše motiv sončne svetlobe, ki pomeni tudi razsvetljenje ali spoznanje prisotnih $\mathrm{v}$ cerkvi, ki ugotovijo, da je sam bog kronal Mladega kralja in ne insignije (zlata krona, plašč iz hermelina itn.).

Čeprav je danes dan mojega kronanja, jih ne bom nosil, ker so moje oblačilo na statvah žalosti stkale blede roke trpljenja.[...] Ali naj radost nosi, kar je trpljenje izdelalo? (Wilde 2000, 81, 83).

Wilde v pravljicah preko glavnih literarnih likov, ki so hkrati mučeniki (trpljenje in žrtve), tematizira svoje življenje in življenje umetnika/zvezdnika v biblijskem, slovesnem in vznesenem slogu Visoke pesmi. Poanta njegovih pravljic ali antipravljic je, da daje prednost »[B]ogu, čigar ime je ljubezen « (str. 153) in ne bogu v cerkvi. Zato tudi duhovnik ali Wildov alter ego začne govoriti o bogu, čigar ime je ljubezen, in blagoslovi »vsa bitja tega božjega sveta« (str. 154). S tem pisatelj po eni strani afirmira vero, po drugi strani pa jo negira in postavi boga ljubezen nad boga v cerkvi, češ da je potrebno slaviti ljubezen in različne vrste ljubezni, tudi med različnimi bitji (ribič in mala morska deklica). 


\section{ŠTUDIJSKI VEČERI}

\section{VIRI IN LITERATURA}

Andersen, Hans Christian. 1998. Pravljice. Prev. Silvana Orel Kos, ilustratorka Marija Lucija Stupica, uvodna beseda Polonca Kovač. Zbirka Veliki pravljičarji. Ljubljana: Mladinska knjiga.

---. 2005. Pravljice: druga knjiga. Prev. Silvana Orel Kos, ilustratorka Suzi Bricelj, spremna beseda Milena Mileva Blažić. Zbirka Veliki pravljičarji. Ljubljana: Mladinska knjiga.

Armstrong, Paul B. (2013) 2015. Kako se literatura igra $z$ možgani? Nevroznanost umetnosti in branja. Prev. Igor Žunkovič. Ljubljana: Znanstvena založba Filozofske fakultete.

Dović, Marijan. 2012. "Model kanonizacije evropskih kulturnih svetnikov.« Primerjalna književnost 35 (3): 71-85.

Grimm, Jakob, in Wilhelm Grimm. 1993. Pravljice 1. Prev. Polonca Kovač. Ljubljana: Mladinska knjiga.

Holland, Merlin, in Rupert Hart-Davis. 200o. The Complete Letters of Oscar Wilde. New York: Henry Holt.

Huizinga, Johan. (1938) 2003. "O izvoru kulture v igri.« V Teorije igre pri Johanu Huizingi, Rogerju Cailloisu in Eugenu Finku, ur. Janez Strehovec, 7-137. Ljubljana: Študentska založba.

Juvan, Marko. 2014. »Karizma teorije." Jezik in slovstvo 59 (2/3): 199-207.

Killeen, Jarlath. 2005. The Faiths of Oscar Wilde. Zbirka Palgrave Studies in Nineteenth-Century Writing and Culture. London: Palgrave Macmillan.

Kümmerling-Meibauer, Bettina. (1999) 2004. Klassiker der Kinder- und Jugendliteratur: Ein internationales Lexikon 2; H-P. Stuttgart in Weimar: Verlag J. B. Metzler.

Lüthi, Max. 2011. Evropska pravljica: forma in narava. Prev. Alenka Veler. Ljubljana: Sophia.

Propp, Vladimir. (1928) 2005. Morfologija pravljice. Prev. Lijana Dejak. Ljubljana: Studia humanitatis.

Uther, Hans-Jörg. (2004) 2011. The Types of International Folktales: A Classification and Bibliography, Based on the System of Antti Aarne and Stith Thompson 1-3. Helsinki: Suomalainen Tiedeakatemia = Academia Scientiarum Fennica.

Wan, Marco. 2011. »A Matter of Style: On Reading the Oscar Wilde Trials as Literature.« Oxford Journal of Legal Studies 31 (4): 709-26.

Wilde, Oscar. 1919. Pravljice. Prev. Alojzij Gradnik. Gorica: Narodna tiskarna.

---. 1921. Pravljice. Prev. Milan Jaklič. Ljubljana: Slovenska socialna matica.

---. 1959. Pravljice. Izbor in prev. Ciril Kosmač, ilustrator Vladimir Lakovič, spremna beseda Josip Vidmar. Ljubljana: Mladinska knjiga. 
---. 1993. Srečni kraljevič. Prev. Ciril Kosmač, ilustratorka Marija Lucija Stupica. Ljubljana: Mladinska knjiga in Delo.

---. 200o. Pravljice. Prev. Ciril Kosmač, ilustratorka Alenka Sottler, spremna beseda Julija Uršič. Zbirka Veliki pravljičarji. Ljubljana: Mladinska knjiga.

\section{SPLETNI VIRI}

Linder, Douglas. S. d. »The Trials of Oscar Wilde: An Account.« Famous Trials. https:// famous-trials.com/wilde/327-home

Sveto pismo: Slovenski standardni prevod 3 (SSP3). (1996) 2021. BIBLIJA.net. Društvo Svetopisemska družba Slovenije. https://www.biblija.net/biblija.cgi?set= $2 \&$ id $13=1 \& \mathrm{l}=\mathrm{sl} \& \mathrm{q} 1=1$

»The Trial of Oscar Wilde, Printed in 1906.« S. d. Britisch Library. https://www.bl.uk/ collection-items/the-trial-of-oscar-wilde-printed-in-1906

Velázquez, Diego. (1656) s. d. "Las Meninas.« Museo Nacional del Prado. https:// www.museodelprado.es/en/the-collection/art-work/las-meninas/gfdc780ogade-48bo-ab8b-edee94ea $877 \mathrm{f}$ 